\title{
Reducing Meat Perishability through Pullulan Active Packaging
}

\author{
Muhammad Jamshed Khan $\mathbb{D}^{1,2}$ Suriya Kumari $\mathbb{D}^{1},{ }^{1}$ Jinap Selamat $\mathbb{D}^{1},{ }^{1}$ Kamyar Shameli $\mathbb{D}^{3}{ }^{3}$ \\ and Awis Qurni Sazili $\mathbb{D}^{1}$ \\ ${ }^{1}$ Institute of Tropical Agriculture and Food Security, Universiti Putra Malaysia (UPM), Serdang 43400, Malaysia \\ ${ }^{2}$ Faculty of Veterinary Sciences, Bahauddin Zakariya University, Multan 60800, Pakistan \\ ${ }^{3}$ Malaysia-Japan International Institute of Technology, Universiti Teknologi Malaysia, Jalan Sultan Yahya Petra, \\ Kuala Lumpur 54100, Malaysia \\ Correspondence should be addressed to Awis Qurni Sazili; awis@upm.edu.my
}

Received 21 July 2020; Revised 21 September 2020; Accepted 4 October 2020; Published 29 October 2020

Academic Editor: Hadi Hashemi Gahruie

Copyright (c) 2020 Muhammad Jamshed Khan et al. This is an open access article distributed under the Creative Commons Attribution License, which permits unrestricted use, distribution, and reproduction in any medium, provided the original work is properly cited.

\begin{abstract}
The provision of safe products from the meat industry has been considered as the major source of protein for maintaining human health. Meat-borne outbreaks are mainly due to Salmonella typhimurium (S. typhimurium), Staphylococcus aureus (S. aureus), Escherichia coli (E. coli), and Clostridium perfringens (C. perfringens), reducing the shelf life and consumer demands. A variety of vulnerable substances, including cholesterol oxidation products (COPs), are generated by the oxidation of meat induced by the microbial infestations. The use of certain biodegradable active packaging, including pullulan active packaging, is being focused by the meat industry due to their safety, stability, and negligible health risks. The potential of pullulan active packaging, incorporated with silver nanoparticles and essential oils, against E. coli, S. typhimurium, Mycoplasma, and other bacterial species is exclusive. Similarly, maintenance of organoleptic properties of meat with nominal oxidative rancidity and limited human health issues can be acquired by pullulan active packaging.
\end{abstract}

\section{Introduction}

The meat industry is facing several issues, and wastage of meat and meat products due to improper processing is the leading issue. According to an alarming report by the Food and Agriculture Organization (FAO) of the United Nations, approximately one-third or over 1.3 billion metric tons of all edible food products, including meat, is wasted annually due to poor practices in harvesting, storage, and transport [1]. Edible food items, especially meat, are also prone to chemical deterioration and microbial infestation causing the stunning threat to consumer health. These deteriorations represent huge economic losses to the food and meat industry every year. Due to the damaged quality of food items, the consumer confidence is being shaken. As a result, economic losses as well as litigation costs borne by food and meat industries are increasing day by day [2].

The losses may be greater in those areas and countries having less processing and sanitary control facilities. The foodborne pathogens in these countries cause a regular health issue for the tourists and consumers in the export regions [3]. The broiler meat industry is facing huge wastage and losses due to improper processing and preservation. Every year, the spoilage of raw meat could be as high as $40 \%$ along with the food supply chain (production, retailing, and consumers) representing a remarkable loss [4]. Alternative packaging strategies, such as designing various pack sizes according to consumer demands and manipulative processing and packaging to maintain food quality and shelf life, have been proposed to reduce these food losses [5]. This reduction in food wastage would enable the nations for sustainable food production and enhance the market development. Globally, more emphasis is done on food safety and it is one of the major objectives of the recent food legislation. The microbiological risks of food products, especially broiler meat, are the major sources of foodborne outbreaks which resulted in a high causalities rate of $13 \%$ around the world [6]. In addition to microbiological safety, 
the colour and lipid stability of meat are the salient parameters of quality influenced by consumer acceptance $[7,8]$. For extending the shelf life of meat and meat products, antimicrobially active, commercially based, economical, and smart preservation solution is "nanotechnology" [9]. Moreover, nanotechnology enables meat preservation with certain biological and chemical procedures by maintaining the compositional integrity, moisture, and gaseous exchange from the meat surface [10]. This advanced technology has a prominent impact on production, storage, processing, transportation, and safety of meat and meat products [11].

For the preservation of meat and meat products, many synthetic and natural antimicrobials/antioxidants have, continuously, been used to reduce meat spoilage with easier commercialization of meat [12]. These products were used either onto the meat surface, in the diet of animals, or along with edible films and coatings (EFCs) mostly referred as "active packaging" [12]. EFCs directly produced or obtained by biomass (polysaccharides and protein), synthesized chemically (i.e., polylactic acid), or obtained from microorganisms (i.e., pullulan) are most preferably utilized as active or biodegradable packaging [13]. The efficacy of EFCs has been investigated by many researchers in previous decades focusing on improvement of their effectiveness when incorporated with natural or metal nanoparticles $[13,14]$.

Pullulan is one of the best used biodegradable polysaccharides capable of forming better, colourless, and tasteless edible active packaging with better oxygen and gas barrier capacities [15]. The incorporation of various antimicrobial agents (including organic acids, essential oils, plant extracts, proteins, and metal nanoparticles) into "pullulan active packaging" can reduce the major microorganism species load in meat products [14].

Based on these facts, this review is aiming on the application of pullulan active packaging for efficient and prolonged meat preservation. In our review, we have provided comprehensive details regarding meat-borne outbreaks, meat oxidation, cholesterol oxidation products (COPs), use of active packaging, and pullulan active packaging for meat preservation.

1.1. Meat-Borne Outbreaks. Meat-borne outbreaks are mostly due to $S$. typhimurium, S. aureus, E. coli, and $C$. perfringens $[6,16]$. The red meat-related outbreaks are mainly due to the infestation by Salmonella species, Listeria species, Staphylococcus species, and Clostridium species, and most of the outbreaks were due to S. typhimurium [5]. In the case of broiler meat-related outbreaks, most of the food poisoning incidences were due to $S$. typhimurium, C. perfringens, and Campylobacter species [5]. Most of the countries are prone to the attack of the bacterial strains in food items due to favourable environmental conditions [17-19]. This problem may be induced by lack of basic principles for food processing, unhygienic food packaging, preservation, and inappropriate microbiological safety measures during the processing of food items especially the meat $[20,21]$.
As preventive measures, the processing, preservation, packaging, storage, transportation, and distribution of meat and meat products should be in a hygienic environment [22]. When meat and poultry sectors do not compromise to compel minimum criteria to ensure the safety and quality of their products, the foodborne outbreaks will not be subsidized [20]. Meat industry must monitor the microbiological load and other biological hazards, causing potential hazards for consumer health, during the production and processing of food items [23]. The meat-related outbreaks occur during cutting and processing, cooking, packaging, transportation, storage, and preservation [24]. These meat-related outbreaks are not only causing serious threats to human beings in the last decade but also deteriorate meat quality in the form of "lipid and protein oxidation" [25].

Implementation of regulatory requirements, good manufacturing, and hygiene practices may be considered as a good methodology to achieve food safety all over the globe [23].

1.2. Meat Oxidation. The pathogenic species of bacteria can deteriorate the quality and shelf life of meat and meat products. Meat deterioration may be experienced as discoloration, off flavour, reduced shelf life, toxic compound formation in meat and meat products, and drip losses of the nutrients $[3,25,26]$. These negative changes in meat and meat products are, mainly, due to oxidation of lipids and protein. This process is affected by the temperature and duration of their storage [27]. The amount of COPs in meat is a reckonable parameter to detect lipid oxidation or "oxidative rancidity" [28]. Similarly, the adaptability of certain microbial strains against new weather and environmental stress is triggered by oxidative rancidity leading towards the production of highly vulnerable substances [29]. The customer demands may be declined by this pessimistic transformation in meat and meat products influenced by environment or storage conditions. These qualitative changes mainly happen due to "oxidation" of lipids resulting in the formation of COPs or protein oxidation [30]. When the packed fresh meat, in a transparent packaging material, is exposed to sunlight/oxygen or improperly stored, the oxidation is initiated, leading towards the reduction in the organoleptic or sensory properties with a higher rejection by the valued customers [31].

Protein oxidation is mainly induced by the bacterial species or due to the oxidative stress [32]. Covalent modification of protein molecules during the oxidation process not only harms the organoleptic properties of the meat and meat products but also influences human health [32].

COPs are formed when the animal-derived food products are heated, cooked dehydrated, stored, and exposed to radiations [33], reducing their demands especially in the persons having high blood cholesterol. Various food products reflect the changing amount of COP formation during processing and storage (Table 1) due to the lipid contents [30].

COP generation is, mainly, conjugated with the amount of fatty acids (unsaturated) and cholesterol in meat, 
TABLE 1: Lipid contents of various food products and the amount of COPs [30].

\begin{tabular}{lcc}
\hline Food products (stored/processed) & Lipid percentages (\%) & COPs (g/100 g lipids) \\
\hline Raw beef & 13.8 & 0.50 \\
Cooked beef & $10.6-12.2$ & $0.40-0.50$ \\
Whole egg powder & 44 & $0.80-1.50$ \\
Whole milk powder & 22.7 & $0.30-0.40$ \\
Grated cheese (Grana type) & $18.4-28.4$ & $0.30-0.40$ \\
Snacks prepared with eggs & $12.7-30.9$ & $0.4-2.60$ \\
Biscuits prepared with eggs & $3.7-27.6$ & $0.20-3.70$ \\
\hline
\end{tabular}

radiations (ultraviolet and gamma), moisture contents, and packaging materials $[33,34]$. Addition of naturally available phenolic compounds (i.e., tannic acid and catechin) to the food products and raw meat may be beneficial to reduce the microbial growth and lipid oxidation [34]. The amount of COPs will be increased when the raw meat is packed and stored while they may be reduced when the processing/ packaging of meat is carried out after cooking [35]. Similarly, vacuum packaging and a low amount of fatty acids in meat can also be considered as "tools" to reduce the COPs in the meat during processing [35]. The maintenance of the quality of meat is still a question mark for the food scientists. These vital issues of the commercial meat industry require appropriate attention by the researchers and government agencies to decrease the losses in near future.

\section{Meat Active Packaging}

The shelf life of meat has been prolonged by the use of synthetic antioxidants including butylated hydroxyl-toluene (BHT), butylated hydroxyl-anisole (BHA), and propyl gallate (PG) to reduce "oxidative rancidity" of fats [35]. However, human health safety is the major concern of the researchers regarding the extensive usage of $\mathrm{BHT}, \mathrm{BHA}$, and PG, switching the direction towards natural products $[33,35]$. Deterioration of meat and meat products is also due to microbial infestation by native microflora in the gut of the animals, through environment, improper handling, transportation, and preservation methods [11]. To overcome these problems, antimicrobials are added to meat and meat products. The preservation of meat by using antimicrobial or antioxidant additives is considered hazardous for human health, and the development of green preservatives is highly required [12]. A study by Nithya and Mohankumar [36] showed that the pathogenic strains of bacteria, especially present in poultry meat, exhibit a maximum "multiple antibiotic resistance index" (MAR) especially S. typhimurium, E. coli, S. aureus, Vibrio cholera (V. cholera), Campylobacter jejuni (C. jejuni), and Listeria monocytogenes (L. monocytogenes). This issue is alarming as the ingestion of these pathogenic bacterial strains can cause huge outbreaks of foodborne problems due to their antibiotic resistance [37]. Moreover, physiochemical changes are continuously induced by these pathogens which may reduce the demands for meat and meat products [37]. EFCs are the best suited and green alternatives to maintain the quality and safety of meat products and to reduce microbial load [14]. The standardized procedures for the synthesis of green packaging products according to industrial requirements and incorporation with "green" antioxidants/antimicrobials are the major challenges to improve meat preservation [14].

In the recent few decades, food scientists have been working on green synthesized preservatives to enhance the quality and shelf life of meat (both fresh and frozen). Ecofriendly, safe, and biodegradable food and meat preservation may help to reduce the risk to the entire ecosystem caused by conventional and synthetic preservatives [38]. This practice may increase the consumer demands towards fresh food materials with extended shelf life and quality ensuring maximum distribution channels all over the globe [37, 38]. Additionally, the consumer acceptances pertaining to the "sensory characteristics" with better health safety and economical aspects in usage are the major objectives for the formation of such green synthesized packaging materials [38]. The meat-based items provide excellent media for bacterial growth which may modify the overall organoleptic, sensory, and chemical parameters, resulting in the decrease of shelf life and higher foodborne illnesses as mentioned by Kerry [39]. Nanotechnology can be a simple, green, and economical solution to lessen these issues. It is assumed that if nanotechnology paces at its current rate in the meat industry, the global hunger can be defeated in a very shorter period with an ample supply of processed meat [40-44]. This advanced technology has a prominent impact on the production, storage, processing, transportation, and safety of poultry products [11, 45-47].

The naturally available/green synthesized products can be used to preserve the various food items especially the meat (Table 2) due to their biodegradable qualities $[16,17]$.

Plant extracts and essential oils cannot be used without any active packaging for the preservation of food due to their variable characteristics and bioavailability. Active edible packaging incorporated with plant extracts and essential oils is a better choice for the long-term preservation of meat and meat products [12, 48-50].

The meat industry requires wide use of natural or green synthesized products to improve the quality of meat and meat products experienced by the consumers [11, 50, 51]. By this practice, excessive usage of synthetic meat preservatives can be reduced to increase the organoleptic and physicochemical properties of meat and meat products $[14,52]$. Antimicrobial/antioxidant efficacy of the active substances in active packaging is, mainly, dependent on their uptake pathways, size, shape, composition, and surface modifications [53-62]. Moreover, the cellular and subcellular distribution of active compounds, from active packaging, to the 
TABLE 2: Natural/green synthesized active packaging [16, 17].

\begin{tabular}{lcc}
\hline Natural/green synthesized packaging products & Type of food & Active ingredient \\
\hline Chitosan & Chicken breasts, cheese, and tilapia fillets & Organic acids \\
Starch/glycerol & Chicken breast meat, tilapia fillets, and cheese & Organic acids \\
Chitosan & Ground beef & Grapefruit extracts \\
Horseradish extracts & Beef & - \\
$\begin{array}{l}\text { Clove, citronella, and cyprus } \\
\text { Seaweed extracts }\end{array}$ & Food packaging in films & Clover oil \\
Alginates & Fruits, vegetables, and meat & - \\
Pullulan & - & Polysaccharides and glycoprotein \\
& Meat, eggs, and fruits & Polysaccharides \\
\hline
\end{tabular}

Table 3: Antimicrobial active packaging.

\begin{tabular}{|c|c|c|c|c|c|}
\hline \multicolumn{6}{|c|}{ Active ingredients } \\
\hline \multirow{2}{*}{$\begin{array}{l}\text { Edible films } \\
\text { and coatings }\end{array}$} & \multicolumn{2}{|c|}{ Incorporated materials } & \multirow[t]{2}{*}{ Active against bacterial species } & \multirow[t]{2}{*}{ Techniques developed } & \multirow[t]{2}{*}{ References } \\
\hline & Nanoparticles & Others & & & \\
\hline Chitosan & Silver & Ciprofloxacin & P. aeruginosa & Antimicrobial loaded films & {$[70]$} \\
\hline Chitosan & Zinc oxide & Carboxymethyl cellulose & S. aureus $P$. aeruginosa, $B$. cereus & Bionanocomposite films & \\
\hline- & - & Essential oils & $\begin{array}{l}\text { S. typhimurium, } \\
\text { L. monocytogenes, E. coli }\end{array}$ & $\begin{array}{l}\text { Low-density polyethylene } \\
\text { packaging (LDPE) }\end{array}$ & \\
\hline- & - & $\begin{array}{l}\text { Phenolic acid-gallic acid, } \\
\text { benzoic acid, and flavonoids }\end{array}$ & L. monocytogenes, C. jejuni & $\begin{array}{l}\text { Flexible bioactive } \\
\text { packaging }\end{array}$ & \\
\hline $\begin{array}{l}\text { Whey } \\
\text { proteins }\end{array}$ & - & Essential oils & $\begin{array}{l}\text { E. coli, L. monocytogenes, } \\
\text { S. aureus, S. enteritidis }\end{array}$ & $\begin{array}{l}\text { Edible films from whey } \\
\text { proteins }\end{array}$ & \\
\hline Chitosan & - & Garlic oil & $\begin{array}{l}\text { E. coli, L. monocytogenes, } \\
\text { S. aureus, B. cereus, } \\
\text { S. typhimurium }\end{array}$ & Edible films from chitosan & \\
\hline Milk protein & - & Organic acids & E. coli and Pseudomonas spp. & $\begin{array}{l}\text { Milk protein-based edible } \\
\text { films }\end{array}$ & \\
\hline- & - & Chitosonium acetate & $\begin{array}{c}\text { L. monocytogenes, S. aureus, } \\
\text { Salmonella spp. }\end{array}$ & Antimicrobial packaging & \\
\hline Cellulose & Silver & - & S. aureus, E. coli & Active food packaging & {$[71]$} \\
\hline Chitosan & Silver & Mandarin essential oil & L. innосиа & Modified coating & {$[72]$} \\
\hline Pullulan & Silver & 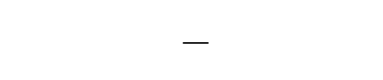 & $\begin{array}{l}\text { B. subtilis, S. aureus, } \\
\text { S. marcescens }\end{array}$ & $\begin{array}{l}\text { Pullulan-silver } \\
\text { nanopackaging }\end{array}$ & {$[73]$} \\
\hline Alginate & Zinc oxide & Glycerol & S. aureus, S. typhimurium & Active packaging & {$[74]$} \\
\hline Alginate & - & $\begin{array}{c}\text { Cinnamon bark oil and } \\
\text { soybean oil }\end{array}$ & $\begin{array}{c}\text { E. coli, L. monocytogenes, and } \\
\text { Salmonella enterica }\end{array}$ & Edible film packaging & {$[75]$} \\
\hline Soybean & Zinc oxide & - & S. aureus and E. coli & Active packaging & {$[76]$} \\
\hline
\end{tabular}

food surface also governs their toxicity risks [61-67]. During the last few years, the development of suitable active packaging, with the lowest toxicity, gained the highest demands by meat and food industry with a better antimicrobial impact and customer safety [14, 67, 68]. Prolonged and microbial free meat preservation requires the application of better technology, such as EFCs, to ensure the quality of processed meat $[52,69]$; Table 3 . It will not only generate more revenue by the meat industry but also maintain customer demand and health.

For the long-term preservation of meat and meat products, emulsifiers and surface-active agents are also used as gas and moisture barriers in the form of "meat coatings" [14]. Pure lipids combined with hydrocolloids (such as protein, starch, cellulose, and their derivatives) may act as a component system able to be applied as "meat coatings" [69]. In fresh and processed meats, lipid incorporation into EFCs makes an excellent water barrier to improve the hydrophobicity, cohesiveness, and flexibility, leading to prolongation of freshness, colour, aroma, tenderness, and microbiological stability. Despite various advantages, protein films may be prone to proteolytic degradation in the presence of enzymes in meat products, or allergenic protein fractions can cause adverse effects on the susceptible people [77].

Polysaccharide-based films and coatings enhance the shelf life of meat and meat products due to the prevention of oxidative rancidity, dehydration, and surface browning [14]. These films dissolve and become integrated into the wrapped meat products exposed to smoke and steam. This parameter reduces the moisture loss from the stored meat products and improves the structure and texture, resulting in higher yields [69]. Moreover, polysaccharidebased films and coatings provide crispiness, hardness, viscosity, compactness, and gel-forming quality to the films. 


\section{Pullulan Active Packaging for Meat Preservation}

Pullulan is an extracellular polysaccharide produced by a fungal species Aureobasidium pullulans [78] which is chemically constructed by repeated maltofructose units (Figure 1). This bioavailable polysaccharide is not exploited yet as "natural preservative and packaging material" except its application against rancidity [79].

Pullulan edible films are considered as more homogeneous and translucent with improved thermal stability and tensile strength when compared with other polysaccharidebased edible films, i.e., chitosan or seaweed edible films [80]. Further, this linear polymer exhibits the viscoelastic behaviour upon the drying and provides the entangled network of the fibers as compared to other bioavailable polymers, presenting less evaporation of water at complete drying [81, 82]. Studies conducted by Diab et al. [38] and Cheng et al. [78] revealed that active packaging obtained from pullulan showed colourless and tasteless texture that was resistant to oil and exhibited very low oxygen permeability with better barrier characteristics as compared to other edible films.

Pullulan active packaging, containing the sweet basil extract (SBE), reduces the chances of weight loss and colour changes in the stored food [82]. Chitosan active packaging (as compared to pullulan) may lead towards the intermolecular hydrogen bond formation instead of intramolecular hydrogen bonding, causing drastic changes in XRD (X-ray diffraction) measurements [82]. These results indicate that pullulan active packaging releases the silver ions in better quantity as compared to chitosan films [82]. Similarly, pullulan active packaging is considered as one of the emerging preservation technologies, to ensure the microbial safety and meat preservation, rarely influenced by external factors [83]. When the food materials are preserved with these packaging, the delicacy and originality of food taste are secured and preserved [14]. A study conducted by Karolina et al. [15] proved that pullulan active packaging preserves the quality of all food items (including fruits and meat) with safety against physical and mechanical damages. Incorporation of nanoparticles in pullulan film to control the foodborne pathogens of meat and meat products provided a new chapter in food and meat processing $[84,85]$.

3.1. Mechanism of Action. The incorporation of nanoparticles into pullulan provides tremendous antimicrobial activity against $E$. coli and L. monocytogenes by slow release of inorganic nanoparticles to targeted bacterial cells [86-88]. The delivery of specific "antimicrobial" substance directly to the surface of meat can reduce the population of various bacterial strains [89]. Antimicrobial mechanism of any antimicrobial substance incorporated into pullulan active packaging includes the following:

(a) Prolongation of the lag phase of growth of bacteria/ fungi [55]

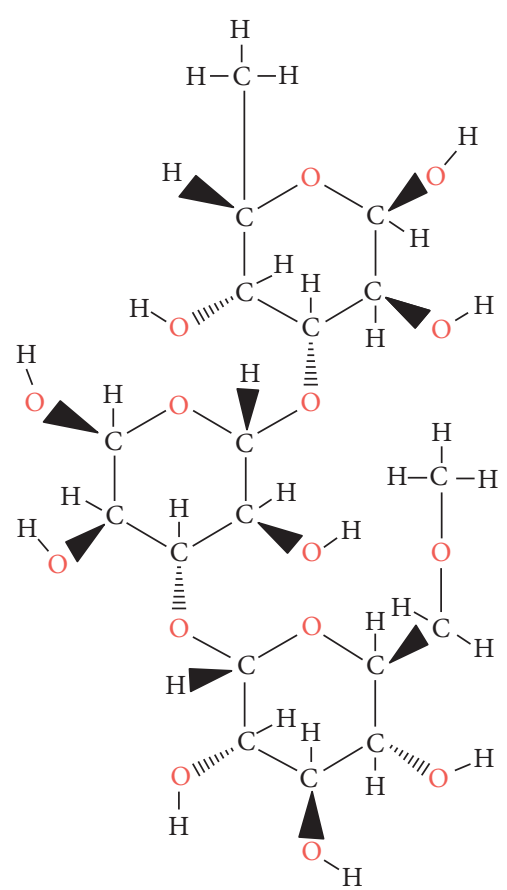

Figure 1: Pullulan chemical structure with repeated maltofructose units.

(b) Cell wall damage [62]

(c) Formation of holes and gaps in the outer membrane of bacterial/fungal cells [54]

(d) Destruction of the outer and inner membrane due to the penetration of metabolites into the bacterial/ fungal cells resulting in the death of the target organism [54]

(e) Loss of integrity of cell membrane and cytoplasmic membrane which increase bacterial/fungal cell permeability $[57,58]$

The antimicrobials or the active substances include silver nanoparticles, gold nanoparticles, $\mathrm{TiO}_{2}$ nanoparticles, essential oils, and certain bacteriocins [90]. The bacteriocins are the peptides (proteins) synthesized by the ribosome of one strain of bacteria with an antimicrobial capacity against their allied strains [91, 92]. The delivery of nanoparticles, essential oils, and bacteriocins, incorporated in pullulan edible films, direct to the surface of meat can maintain its quality and prolongs the storage duration [91]. This is, directly, related to the fact that pullulan can adhere to the moist surface of meat and releases the "active agents" (nanoparticles, essential oils, and bacteriocins) right into the surface slowly [86]. It can surround nanoparticles in the form of a thin layer as well resulting in the reduction of the number of harmful bacterial strains [46].

Incorporation of nanoparticles/active substances from different origins, into pullulan, to formulate "active packaging" has been reported by many researchers in the last two decades, as a green preservative, to prolong the shelf life and quality of meat $[85,88,91]$ (Table 4 ). 
TABLe 4: Pullulan active packaging for meat preservation.

\begin{tabular}{|c|c|c|c|}
\hline & Effective against bacterial strains & Type of food items & References \\
\hline Pullulan with nanoparticles/essential oils & $\begin{array}{l}\text { S. aureus, L. monocytogenes, S. typhimurium, and E. coli } \\
\text { O157:H7 }\end{array}$ & Poultry meat products & {$[84]$} \\
\hline Pullulan with zinc nanoparticles & $\begin{array}{c}\text { S. aureus, L. monocytogenes, E. coli } \mathrm{O} 157: \mathrm{H} 7 \text {, and } \\
\text { S. typhimurium }\end{array}$ & Turkey meat & {$[86]$} \\
\hline Pullulan with silver nanoparticles & S. aureus and L. monocytogenes. & Turkey meat & {$[86]$} \\
\hline Pullulan with silver nanoparticles & L. monocytogenes and S. aureus & Turkey deli meat & {$[86]$} \\
\hline Pullulan with LAE-nisin Z & S. aureus, L. monocytogenes, and E. coli $\mathrm{O} 157: \mathrm{H} 7$ & $\begin{array}{c}\text { Ham deli meat and raw } \\
\text { beef }\end{array}$ & [87] \\
\hline $\begin{array}{l}\text { Pullulan with lauric arginate (LAE) and } \\
\text { nisin } Z\end{array}$ & S. typhimurium and S. enteritidis & Turkey breast & {$[88]$} \\
\hline
\end{tabular}

Similarly, antimicrobial characteristics of silver nanoparticles (AgNPs) incorporated into active packaging, against various dangerous species of bacteria, cannot be ignored [79]. AgNPs synthesized from curcumin, pullulan, cellulose, and collagen sources can act as a strong antibacterial and antifungal agent [46, 91, 92]. For the customer health protection and product quality maintenance, the green synthesized AgNPs from pullulan (as stabilizing/reducing agent) can show tremendous results [14]. The use of "pullulan active packaging," incorporated with AgNPs is increasing day by day in the meat industry as a "green" preservative [85]. However, various factors may also affect the antimicrobial activity of "pullulan active packaging," incorporated with AgNPs including size, shape, and crystallographic structure of AgNPs [92]. Ganduri et al. [73] proved that the AgNPs, synthesized from the increasing amount of pullulan concentrations, showed an intense antimicrobial capacity for meat preservation [69]. Moreover, pullulan-mediated AgNPs can be utilized as an "active substance" for the preservation of meat and meat products, but the size, hydrophilic-hydrophobic character of pullulan-mediated AgNPs, and their concentration are the major factors affecting their efficacy $[46,93]$. For the preservation of meat and meat products, the incorporation of silver nanoparticles into pullulan films to formulate "active packaging" is ever-increasing [85]. The conjugation of antimicrobial abilities of pullulan and AgNPs can improve the shelf life and quality of meat products $[46,92]$. Khalaf et al. [86] reported that pullulan active films, containing silver nanoparticles, surprisingly inactivated the lethal impacts of L. monocytogenes and S. aureus causing a reduction in the spoilage of meat and meat products. The mentioned study was performed on turkey meat showed the antimicrobial activity of pullulan-incorporated silver nanoparticles for the safe processing of white meat. The stability of pullulan active packaging, incorporated with AgNPs, at a wide range of storage temperature, i.e., $4^{\circ} \mathrm{C}$ to $25^{\circ} \mathrm{C}$, showed a novel route for safe, healthier, and biodegradable meat packaging [86, 94-97].

The superior biocompatibility, nonimmunogenic, nonmutagenic, noncarcinogenic, and easily degradable properties of pullulan-based active packaging can be considered as a better choice to improve the quality and shelf life of meat in preservation studies [98-100].

These advancements for meat processing can further reduce the microbial contamination in broiler meat with improved quality $[101,102]$.

\section{Conclusion}

The use of synthetic antioxidants (butylated hydroxyl-toluene, butylated hydroxyl-anisole, and propyl gallate) and antimicrobials, to overcome meat oxidation and perishability, is imposing serious health issues in human beings. The biodegradable pullulan active packaging, incorporated with any active substance (i.e., AgNPs and essential oils) may be adopted as the alternative technology due to their superior antimicrobial capacity against $S$. typhimurium, E. coli, S. aureus, C. perfringens, $V$. cholera, C. jejuni, S. enteritidis, and L. monocytogenes. Due to the effect of pullulan active packaging on microbial population reduction, the oxidative and compositional stability of meat is remained unchanged, resulting in higher customer safety. Furthermore, antimicrobial activity of AgNPs released from the active packaging is one of the complex phenomena influenced by their better composition, appropriate size, and shape. The green and reliable pullulan active meat packaging can not only reduce the chances of meat perishability but also lower down the oxidative rancidity, generation of COPs, and compositional losses.

\section{Data Availability}

No experimental data was utilized in this manuscript. The literature and referred journal research papers were considered.

\section{Conflicts of Interest}

The authors declare that they have no conflicts of interest.

\section{Authors' Contributions}

Sazili AQ, Kumari S, and Khan MJ conceptualized the study; Khan MJ was involved in data curation and responsible for software development and wrote the original draft; Khan MJ, Sazili AQ, and Kumari S investigated the study; Khan MJ, 
Kumari S, Selamat J, Shameli K, and Sazili AQ wrote, reviewed, and edited the manuscript.

\section{References}

[1] FAO, October 2018, http://www.fao.org/index en.htm.

[2] R. L. Scharff, "Economic burden from health losses due to foodborne illness in the United States," Journal of Food Protection, vol. 75, no. 1, pp. 123-131, 2012.

[3] J. C. Buzby and T. Roberts, "Economic costs and trade impacts of microbial food borne illness," World Health Statistics, vol. 50, no. 1-2, pp. 57-66, 1997.

[4] J. Cerveny, J. D. Meyer, and P. A. Hall, Food Microbiology and Food Safety, W. H. Sperber and M. P. Doyle, Eds., Springer, New York, NY, USA, 2009.

[5] CDC, November 2018, http://www.cdc.gov/features/ dsFoodborneOutbreaks/.

[6] Y. Motarjemi and H. Lelieveld, Fundamentals in Management of Food Safety in the Industrial Setting: Challenges and Outlook of the 21st Century Food Safety Management, Chapter 1, Academic Press, San Diego, CA, USA, 2014.

[7] M. Calatayud, C. López-de-Dicastillo, G. López-Carballo, D. Vélez, P. H. Muñoz, and R. Gavara, "Active films based on cocoa extract with antioxidant, antimicrobial and biological applications," Food Chemistry, vol. 39, no. 1-4, pp. 51-58, 2013.

[8] W. H. Sperber, "Introduction to the microbial spoilage of foods and beverages," in Compendium of the Microbial Spoilage of Foods and Beverages, W. H. Sperber and M. P. Doyle, Eds., pp. 1-40, Springer, New York, NY, USA, 2010.

[9] M. A. Morris, S. C. Padmanabhan, M. C. Cruz-Romero, E. Cummins, and J. P. Kerry, "Development of active, nanoparticle, antimicrobial technologies for muscle-based packaging applications," Meat Science, vol. 132, pp. 163-178, 2017.

[10] I. M. Carmen, P. P. Chithra, H. Qingrong, T. Paul, L. Sean, and J. L. Kokini, "Nanotechnology: a new frontier in food science," Food Technology, vol. 57, pp. 24-29, 2003.

[11] S. Otles and B. Yalcin, "Smart food packaging," Elektroni. Czaso. Nauk.Dzied. Logistyki.vol. 4, no. 3, pp. 1-7, 2008.

[12] V. Velasco and P. Williams, "Improving meat quality through natural antioxidants," Chilean Journal of Agricultural Research, vol. 71, no. 2, pp. 313-322, 2011.

[13] A. R. V. Ferreira, V. D. Alves, and I. M. Coelhoso, "Polysaccharide-based membranes in food packaging applications," Membranes, vol. 6, no. 2, pp. 1-17, 2016.

[14] I. Sánchez-Ortega, B. E. García-Almendárez, E. M. SantosLópez, A. Amaro-Reyes, J. E. Barboza-Corona, and C. Regalado, "Antimicrobial edible films and coatings for meat and meat products preservation," The Scientific World Journal, vol. 2014, pp. 1-18, Article ID 248935, 2014.

[15] K. Kraśniewska, I. Ścibisz, M. M. Gniewosz, M. Mitek, K. Pobiega, and A. Cendrowski, "Effect of pullulan coating on postharvest quality and shelf-life of highbush blueberry," Vaccinium Corymbosum L.)," Materials, vol. 10, no. 8, p. 965, 2017.

[16] V. Mittal, "Polymer layered silicate nanocomposites: a review," Materials, vol. 2, pp. 992-1057, 2009.

[17] R. Domínguez, F. J. Barba, B. Gómez et al., "Active packaging films with natural antioxidants to be used in meat industry: a review," Food Research International, vol. 113, no. 6, pp. 93-101, 2018.
[18] S. Galus and J. Kadzińska, "Food applications of emulsionbased edible films and coatings," Trends in Food Science \& Technology, vol. 45, no. 2, pp. 273-283, 2015.

[19] A. Bahrami, R. Rezaei, M. Sowti, B. Ghanbarzadeh, and R. Salehi, "Physico-mechanical and antimicrobial properties of tragacanth/hydroxypropyl methylcellulose/beeswax edible films reinforced with silver nanoparticles," International Journal of Biological Macromolecules, vol. 11, 2018.

[20] N. Smigic, D. Antic, B. Blagojevic, I. Tomasevic, and I. Djekic, "The level of food safety knowledge among meat handlers," British Food Journal, vol. 118, no. 1, pp. 9-25, 2016.

[21] W. P. Sharifa-Ezat, D. Netty, and G. Sangaran, "Paper review of factors, surveillance and burden of food borne disease outbreak in Malaysia," Malaysian Journal Of Public Health Medicine, vol. 13, no. 2, pp. 98-105, 2013.

[22] M. Boström, A. M. Jönsson, S. Lockie, A. P. J. Mol, and P. Oosterveer, "Sustainable and responsible supply chain governance: challenges and opportunities," Journal of Cleaner Production, vol. 107, pp. 1-7, 2015.

[23] N. Karabasil, T. Bošković, M. Dimitrijević et al., "Food safety - the roles and responsibilities of different sectors," IOP Conference Series: Earth \& Environment Science, vol. 85, no. $1,2017$.

[24] D. Dave and A. E. Ghaly, "Meat spoilage mechanisms and preservation techniques: a critical review," The American Journal of Agriculture \& Biological Science, vol. 6, no. 4, pp. 486-510, 2011.

[25] B. Palmieri and V. Sblendorio, “'Oxidative stress tests: overview on reliability and use", part II," European Review for Medical \& Pharmacological Science, vol. 11, pp. 383-399, 2007.

[26] C. Contini, R. Álvarez, M. O'Sullivan et al., "Effect of an active packaging with citrus extract on lipid oxidation and sensory quality of cooked Turkey meat," Meat Science, vol. 96, no. 3, pp. 1171-1176, 2014.

[27] A. Gupta, W. L. Low, I. Radecka, S. T. Britland, M. C. I. Mohd Amin, and C. Martin, "Characterisation and in vitro antimicrobial activity of biosynthetic silver-loaded bacterial cellulose hydrogels," Journal of Microencapsulation, vol. 33, no. 8, pp. 725-734, 2016.

[28] A. Grau, F. Guardiola, S. Grimpa, A. C. Barroeta, and R. Codony, "Oxidative stability of dark chicken meat through frozen storage: influence of dietary fat and $\alpha$-tocopherol and ascorbic acid supplementation," Poultry Science, vol. 80, no. 11, pp. 1630-1642, 2001.

[29] P. Flavia, V. Zorica, and B. Delia, "Effects of temperature and storage time on the quality of alimentary animal fats," International Food Research Journal, vol. 21, no. 4, pp. 15071513, 2014.

[30] G. Lercker and M. T. Rodriguez-Estrada, "Cholesterol oxidation: presence of 7-ketocholesterol in different food products," Journal of Food Composition and Analysis, vol. 13, no. 4, pp. 625-631, 2000.

[31] M. F. Caboni, G. Fedrizzi, and G. Lercker, Sulla presenza di alcuniprodotti diossidazionenella carne bovina, Atti del workshop CNR-RAISA Flair Flow, Udine, Italy Europe, 1995.

[32] O. P. Soladoye, J. Manuel, J. L. Aalhus, J. S. Phyllis, and E. Mario, "Protein oxidation in processed meat: mechanisms and potential implications on human health," Food Sciencee Food Safety, vol. 14, no. 2, pp. 1541-4337, 2015.

[33] M. I. Khan, J. S. Min, S. O. Lee et al., "Cooking, storage, and reheating effect on the formation of cholesterol oxidation 
products in processed meat products," Lipids in Health \& Diseases, vol. 14, p. 89, 2015.

[34] S. Maqsood, A. Abushelaibi, K. Manheem, A. Al Rashedi, and I. T. Kadim, "Lipid oxidation, protein degradation, microbial and sensorial quality of camel meat as influenced by phenolic compounds," LWT - Food Science and Technology, vol. 63, no. 2, pp. 953-959, 2015.

[35] M. Du, K. C. Nam, and D. U. Ahn, "Cholesterol and lipid oxidation products in cooked meat as affected by raw-meat packaging and irradiation and by cooked-meat packaging and storage time," Journal of Food Science, vol. 66, no. 9, pp. 1396-1401, 2001.

[36] K. Nithya and A. Mohankumar, "Incidence and antibiotic resistance of plasmid borne avian pathogens from poultry," Asian Journal of Microbiology, Biotechnology and Environmental Science, vol. 8, no. 3, pp. 551-556, 2006.

[37] A. Mutalib, N. Azira, S. Amin-Nordin, K. Sakai, and Y. Shirai, "An overview of foodborne illness and food safety in Malaysia," International Food Research Journal, vol. 22, no. 3, pp. 896-901, 2015.

[38] T. Diab, C. G. Biliaderis, D. Gerasopoulos, and E. Sfakiotakis, "Physicochemical properties and application of pullulan edible films and coatings in fruit preservation," Journal of the Science of Food and Agriculture, vol. 81, no. 10, pp. 988-1000, 2001.

[39] J. P. Kerry, New packaging technologies, materials and formats for fast-moving consumer products Innovations in food packaging, H. Han, Ed., pp. 549-584, Academic Press, San Diego, CA, USA, 2nd edition, 2014.

[40] A. C. Carmen, N. G. Lía, and K. F. Silvia, "Development of edible films and coatings with antimicrobial activity," Food Bioprocess Technology, vol. 434, no. 1, p. 11947, 2010

[41] D. J. Troy and J. P. Kerry, "Consumer perception and the role of science in the meat industry," Meat Science, vol. 86, no. 1, pp. 214-226, 2010.

[42] M. Friedman, P. R. Henika, and R. E. Mandrell, "Bactericidal activities of plant essential oils and some of their isolated constituents against Campylobacter jejuni, Escherichia coli, Listeria monocytogenes, and Salmonella enterica," Journal of Food Protection, vol. 65, no. 10, pp. 1545-1560, 2002.

[43] N. A. Olasupo, D. J. Fitzgerald, M. J. Gasson, and A. Narbad, "Activity of natural antimicrobial compounds against Escherichia coli and Salmonella enterica serovar typhimurium," Letters in Applied Microbiology, vol. 37, no. 6, pp. 448-451, 2003.

[44] S. Y. Kim, D. H. Kang, J. K. Kim et al., “Antimicrobial activity of plant extracts against Salmonella Typhimurium, Escherichia coli O157:H7, and Listeria monocytogenes on fresh lettuce," Journal of Food Science, vol. 76, pp. 41-46, 2011.

[45] A. Synowiec, M. Gniewosz, K. Kraśniewska, J. L. Przybył, K. Bączek, and Z. Węglarz, "Antimicrobial and antioxidant properties of pullulan film containing sweet basil extract and an evaluation of coating effectiveness in the prolongation of the shelf life of apples stored in refrigeration conditions," Innovative Food Sciencee Emerging Technology, vol. 23, pp. 171-181, 2014.

[46] M. J. Khan, S. Kumari, K. Shameli, J. Selamat, and A. Q. Sazili, "Green synthesis and characterization of pullulan mediated silver nanoparticles through ultraviolet irradiation," Materials, vol. 12, no. 2382, pp. 1-12, 2019.

[47] T. U. Mahmoud, "Silver nanoparticles in poultry production," Journal ofAdvanced Veterinary Research, vol. 2, pp. 303-306, 2008.
[48] J. I. Cho, S. H. Lee, J. S. Lim, Y. J. Koh, H. S. Kwak, and I. G. Hwang, "Detection and distribution of food-borne bacteria in ready-to-eat foods in Korea," Food Science and Biotechnology, vol. 20, no. 2, pp. 525-529, 2011.

[49] P. J. P. Espitia, N. d. F. F. Soares, J. S. d. R. Coimbra, N. J. de Andrade, R. S. Cruz, and E. A. A. Medeiros, "Zinc oxide nanoparticles: synthesis, antimicrobial activity and food packaging applications," Food and Bioprocess Technology, vol. 5, no. 5, pp. 1447-1464, 2012.

[50] B. Panea, G. Ripoll, J. González, A. Fernández-Cuello, and P. Albertí, "Effect of nanocomposite packaging containing different proportions of $\mathrm{ZnO}$ and $\mathrm{Ag}$ on chicken breast meat quality," Journal of Food Engineering, vol. 123, pp. 104-112, 2013.

[51] J. P. Kerry, M. N. O’Grady, and S. A. Hogan, "Past, current and potential utilisation of active and intelligent packaging systems for meat and muscle-based products: a review," Meat Science, vol. 74, no. 1, pp. 113-130, 2006.

[52] Y. Wyser, M. Adams, M. Avella et al., "Outlook and challenges of nanotechnologies for food packaging," Packaging Technology and Science, vol. 29, no. 12, pp. 615-648, 2016.

[53] F. Alexis, E. Pridgen, L. K. Molnar, and O. C. Farokhzad, "Factors affecting the clearance and biodistribution of polymeric nanoparticles," Molecular Pharmaceutics, vol. 5, no. 4, pp. 505-515, 2008.

[54] S. Salatin and A. Yari Khosroushahi, "Overviews on the cellular uptake mechanism of polysaccharide colloidal nanoparticles," Journal of Cellular and Molecular Medicine, vol. 21, no. 9, pp. 1668-1686, 2017.

[55] H. Li, T. Tsui, and W. Ma, "Intracellular delivery of molecular cargo using cell-penetrating peptides and the combination strategies," International Journal of Molecular Sciences, vol. 16, no. 8, pp. 19518-19536, 2015.

[56] H. Kang, S. Mintri, A. V. Menon, H. Y. Lee, H. S. Choi, and J. Kim, "Pharmacokinetics, pharmacodynamics and toxicology of theranostic nanoparticles," Nanoscale, vol. 7, no. 45, pp. 18848-18862, 2015.

[57] B. Yameen, W. I. Choi, C. Vilos, A. Swami, J. Shi, and O. C. Farokhzad, "Insight into nanoparticle cellular uptake and intracellular targeting," Journal of Controlled Release, vol. 190, pp. 485-499, 2014.

[58] P. Foroozandeh and A. A. Aziz, "Insight into cellular uptake and intracellular trafficking of nanoparticles," Nanoscale Research Letters, vol. 6, no. 13, pp. 1-12, 2018.

[59] M. Mahmoudi, J. Meng, X. Xue et al., "Interaction of stable colloidal nanoparticles with cellular membranes," Biotechnology Advances, vol. 32, no. 4, pp. 679-692, 2014.

[60] J. P. Peñaloza, V. Márquez-Miranda, M. Cabaña-Brunod, R. Reyes-Ramírez, F. M. Llancalahuen, and C. Vilos, "Intracellular trafficking and cellular uptake mechanism of PHBV nanoparticles for targeted delivery in epithelial cell lines," Journal of Nanobiotechnology, vol. 15, no. 1, p. 1, 2017.

[61] J. Lovrić, H. S. Bazzi, Y. Cuie, G. R. Fortin, F. M. Winnik, and D. Maysinger, "Differences in subcellular distribution and toxicity of green and red emitting CdTe quantum dots," Journal of Molecular Medicine (Berlin, Germany), vol. 83, no. 5, pp. 377-385, 2005.

[62] Z. Garaiova, S. P. Strand, N. K. Reitan et al., "Cellular uptake of DNA-chitosan nanoparticles: the role of clathrin- and caveolae-mediated pathways," International Journal of Biological Macromolecules, vol. 51, no. 5, pp. 1043-1051, 2012.

[63] A. Panariti, G. Miserocchi, and I. Rivolta, "The effect of nanoparticle uptake on cellular behavior: disrupting or enabling function," Nanotechnology Science, vol. 5, p. 87, 2012. 
[64] S. Nagayama, K.-i. Ogawara, Y. Fukuoka, K. Higaki, and T. Kimura, "Time-dependent changes in opsonin amount associated on nanoparticles alter their hepatic uptake characteristics," International Journal of Pharmaceutics, vol. 342, no. 1-2, pp. 215-221, 2007.

[65] C. M. Goodman, C. D. McCusker, T. Yilmaz, and V. M. Rotello, "Toxicity of gold nanoparticles functionalized with cationic and anionic side chains," Bioconjugate Chemistry, vol. 15, no. 4, pp. 897-900, 2004.

[66] K. A. Dawson, A. Salvati, and I. Lynch, "Nanotoxicology: nanoparticles reconstruct lipids," Nature Nanotechnology, vol. 4, no. 2, pp. 84-85, 2009.

[67] G. Orr, D. J. Panther, J. L. Phillips et al., "Submicrometer and nanoscale inorganic particles exploit the actin machinery to be propelled along microvilli-like structures into alveolar cells," ACS Nano, vol. 1, no. 5, pp. 463-475, 2007.

[68] Y. Huang, L. Mei, X. Chen, and Q. Wang, "Recent developments in food packaging based on nanomaterials," Nanomaterials, vol. 2018, pp. 1-29, 2018.

[69] C. N. Cutter, "Opportunities for bio-based packaging technologies to improve the quality and safety of fresh and further processed muscle foods," Meat Science, vol. 74, no. 1, pp. 131-142, 2006.

[70] A. P. Ananda, H. M. Manukumar, S. Umesha et al., "A relook at food packaging for cost effective by incorporation of novel technologies," Journal of Packaging Technology \& Research, vol. 17, no. 4, p. 0011, 2017.

[71] M. R. De Moura, L. H. C. Mattoso, and V. Zucolotto, "Development of cellulose-based bactericidal nanocomposites containing silver nanoparticles and their use as active food packaging," Journal of Food Engineering, vol. 109, no. 3, pp. 520-524, 2012.

[72] F. Donsì, E. Marchese, P. Maresca et al., "Green beans preservation by combination of a modified chitosan basedcoating containing nanoemulsion of Mandarin essential oil with high pressure or pulsed light processing," Postharvest Biology and Technology, vol. 106, pp. 21-32, 2015.

[73] V. S. R. K. Ganduri, M. Ushakiranmayi, M. Vijayalakshmi, and P. Sudhakar, "Pullulan- stabilized silver nano particlestheir synthesis, characteruization and application as bacterial agents," Journal of Applied Pharmaceutical Science, vol. 6, no. 7, pp. 27-37, 2016.

[74] A. Akbar and A. K. Anal, "Zinc oxide nanoparticles loaded active packaging, a challenge study against Salmonella typhimurium and Staphylococcus aureus in ready-to-eat poultry meat," Food Control, vol. 38, no. 1, pp. 88-95, 2014.

[75] Y. Anal, Q. Ma, F. Critzer, P. M. Davidson, and Q. Zhong, "Physical and antibacterial properties of alginate films containing cinnamon bark oil and soybean oil," $L W T$ - Food Science and Technology, vol. 64, no. 1, pp. 423-430, 2015.

[76] D. Salarbashi, S. A. Mortazavi, M. S. Noghabi et al., "Development of new active packaging film made from a soluble soybean polysaccharide incorporating $\mathrm{ZnO}$ nanoparticles," Carbohydrate Polymers, vol. 140, pp. 220-227, 2016, https://doi.org/10.1016/j.carbpol. 2015.12.043.

[77] A. Gennadios, M. A. Hanna, and L. B. Kurth, "Application of edible coatings on meats, poultry and seafoods: a review," LWT - Food Science and Technology, vol. 30, no. 4, pp. 337-350, 1997.

[78] K. Cheng, A. Demirci, and J. M. Catchmark, "Pullulan: biosynthesis, production, and applications," Applied Microbiology\&Biotechnology, vol. 2011, no. 92, pp. 29-44, 2011.
[79] T. V. Duncan, "Applications of nanotechnology in food packaging and food safety: barrier materials, antimicrobials and sensors," Journal of Colloid and Interface Science, vol. 363, no. 1, pp. 1-24, 2011.

[80] P. Ogzhan and F. Yangilar, "Pullulan: production and usage in food industry," African Journal of Food SciencedTechnology, vol. 4, no. 3, pp. 57-63, 2013.

[81] Q. Xiao, Z. Zhao, and L. T. Lim, "Structure evolution of pullulan-alginate edible films during drying studied by lowfield NMR," Journal of Food Process Engineering, vol. 41, no. $1,2018$.

[82] W. Jia, Z. Fang, L. Yue, C. F. Shoemaker, and W. Xia, "Preparation and characterization of pullulan - chitosan and pullulan - carboxymethyl chitosan blended films," Food Hydrocolloids, vol. 30, no. I, pp. 82-91, 2013.

[83] M. A. Cerqueira, A. I. Bourbon, A. C. Pinheiro et al., "Galactomannans use in the development of edible films/ coatings for food applications," Trends in Food Science \& Technology, vol. 22, no. 12, pp. 662-671, 2011.

[84] M. K. Morsy, H. H. Khalaf, A. M. Sharoba, H. H. El-Tanahi, and C. N. Cutter, "Incorporation of essential oils and nanoparticles in pullulan films to control foodborne pathogens on meat and poultry products," Journal of Food Science, vol. 79, no. 4, pp. 675-684, 2014.

[85] A. Synowiec, M. Gniewosz, K. Kraśniewska, J. L. Przybył, K. Bączek, and Z. Węglarz, "Antimicrobial and antioxidant properties of pullulan film containing sweet basil extract and an evaluation of coating effectiveness in the prolongation of the shelf life of apples stored in refrigeration conditions," Innovative Food Science \& Emerging Technologies, vol. 23, pp. 171-181, 2014.

[86] H. Khalaf, A. Sharoba, H. El-Tanahi, and M. Morsy, "Stability of antimicrobial activity of pullulan edible films incorporated with nanoparticles and essential oils and their impact on Turkey deli meat quality," Journal of Food and Dairy Sciences, vol. 4, no. 11, pp. 557-573, 2013.

[87] K. Song and Y. Qi, Electrospun Nanofibers with Antimicrobial Properties, WoodHead Publishing, Duxford, UK, 2017.

[88] R. Pattanayaiying, A. H-Kittikun, and C. N. Cutter, "Incorporation of nisin $\mathrm{Z}$ and lauric arginate into pullulan films to inhibit foodborne pathogens associated with fresh and ready-to-eat muscle foods," International Journal of Food Microbiology, vol. 207, pp. 77-82, 2015.

[89] V. Trinetta, J. D. Floros, and C. N. Cutter, "Sakacin A-containing pullulan film: an active packaging system to control epidemic clones of listeria monocytogenes in ready-to-eat foods," Journal of Food Safety, vol. 2010, no. 30, pp. 366-381, 2010.

[90] Y. Shih-Chun, L. Chih-Hung, T. Calvin, A. Sung, and F. Jia-You, "Antibacterial activities of bacteriocins: application in foods and pharmaceuticals," Frontier in Microbiology, vol. 10, 2014.

[91] M. K. Morsy, A. M. Sharoba, H. H. Khalaf, H. H. El-Tanahy, C. N. Cutter, and C. N. Cutter, "Efficacy of antimicrobial pullulan-based coating to improve internal quality and shelflife of chicken eggs during storage," Journal of Food Science, vol. 80, no. 5, pp. M1066-M1074, 2015.

[92] M. J. Khan, K. Shameli, A. Sazili, J. Selamat, and S. Kumari, "Rapid green synthesis and characterization of silver nanoparticles arbitrated by curcumin in an alkaline medium," Molecules, vol. 24, no. 719, pp. 1-12, 2019.

[93] A. V. Fedotova, A. G. Snezhko, O. A. Sdobnikova et al., "Packaging materials manufactured from natural polymers modified with silver nanoparticles," International Polymer Science and Technology, vol. 37, no. 10, pp. 59-64, 2010. 
[94] M. Cruz-Romero and J. P. Kerry, Packaging Systems and Materials Used for Meat Products with Particular Emphasis on the Use of Oxygen Scavenging systems: Emerging Technologies In Meat Processing, Wiley Online Library, Hoboken, NY, USA, 2017.

[95] I. Fernández-Pan, X. Carrión-Granda, and J. I. Maté, “Antimicrobial efficiency of edible coatings on the preservation of chicken breast fillets," Food Control, vol. 36, no. 1, pp. 69-75, 2014.

[96] M. Gniewosz and A. Synowiec, "Antibacterial activity of pullulan films containing thymol," Flavour\&Fragance Journal, vol. 26, pp. 289-395, 2011.

[97] C. T. Jutaporn, C. Suphitchaya, and W. Thawien, "Antimicrobial activity and characteristics of edible films incorporated with phayom wood (shoreatolura) extract," International Food Research Journal, vol. 18, pp. 39-54, 2011.

[98] H. Li, H. Sun, J. Zhang, and K. Pang, "Highly sensitive and simultaneous determination of sixteen sulphonamide antibiotics, four acetyled metabolites and trimethoprim in meat by rapid resolution liquid chromatography-tandem mass spectrometry," Food Control, vol. 31, no. 2, pp. 359-365, 2013.

[99] L. Mihaiu, A. Lapusan, R. Tanasuica et al., "First study of salmonella in meat in Romania," The Journal of Infection in Developing Countries, vol. 8, no. 01, pp. 050-058, 2014.

[100] K. Karabasil, T. Bošković, M. Dimitrijević et al., "Food safety - the roles and responsibilities of different sectors: IOP Conference Series," Earth EnvironmentScience, vol. 85, Article ID 012023, 2017.

[101] P. Nagar, I. Chauhan, and Y. Mohd, "Insights into polymers: film formers in mouth dissolving films," Drug Invention Today, vol. 3, no. 12, pp. 280-289, Article ID 201206, 2011.

[102] J. Weiss, M. Gibis, V. Schuh, and H. Salminen, "Advances in ingredient and processing systems for meat and meat products," Meat Science, vol. 86, no. 1, pp. 196-213, 2010.

[103] A. Kapetanakou, S. Manios, and P. Skandamis, "Application of edible films and coatings on food," Novel Food Preservation and Microbial Assessment Techniques, vol. 52, pp. 237-273, 2014.

[104] E. Trovatti, S. C. M. Fernandes, L. Rubatat et al., "Pullulannanofibrillated cellulose composite films with improved thermal and mechanical properties," Composites Science and Technology, vol. 72, no. 13, pp. 1556-1561, 2012. 